\author{
Marta Dragičević Prtenjača, $\mathrm{PhD}$ \\ Assistant Professor, University of Zagreb Faculty of Law
}

\title{
THE NEW POSSIBILITY OF METHODOLOGY OF SENTENCING IN CROATIA DE LEGE FERENDA - THE NEW IMPROVED FORMULA ${ }^{1}$
}

\author{
$U D K: 343(497.5)$ \\ DOI: $10.31141 /$ ZRPFS.2020.57.136.585 \\ Izvorni znanstveni rad \\ Primljeno: 20. ožujka 2019.
}

The inconsistent case law seems to be a relatively big problem because it affects confidence in justice and legal certainty. The background of this problem is process of sentencing. In Croatia there is no methodology for determining the punishment. Of course, the Croatian Penal Code has the norms which regulate the purpose of punishment and it, in some generic form, stipulates the circumstances which can be relevant for determining the punishment. However, it does not say anything about the process itself nor does it define the methodology to carry it out. During this process the court has to bear in mind the purpose of sentencing and the perpetrators guilt, in order for punishment to be proper and would correspond to the severity of the committed offense. Hence, as here is no methodology no one can be sure whether or not this process was lege artis. In that regard author give their proposition of possible solution to this matter. They are suggesting the introduction of non-mandatory 'formula' for sentencing into the Croatian criminal law system. The formula would now be improved And more appropriate than the previous one. Author believe 'the formula' should contribute to the harmonization of case-law in Croatia and to the preservation of the principle of legal certainty and finally the rule of law. Similar solutions already exist in some countries. The Republic of North Macedonia, which incorporates the civil or continental law system, introduced the special Law for the Determination of the Type and Duration of Sentence in 2015, while the United States have been applying the Sentencing Guidelines since 1987.

Key words: inconsistent case-law, sentencing, methodology of sentencing, rule of law, formula

\section{INTRODUCTION}

To be reminded the consistency in the case law is very important from the point of legal certainty as a safeguard of the rule of law. Harmonization of national

1 I would especially like to express my gratitude to Petra Kopić, without whom there wouldn't be a (mathematical expression) formula for sentencing.

In the previous paper which was dealing with the issue of 'Utjecaj (nemetodološkog) odmjeravanja kazne na (ne)ujednačenost sudske prakse u Hrvatskoj i narušavanje tekovine vladavine prava (eng. 'The Influence of (Non-Methodological) Sentencing on the (In)Consistency of the Case Law in Croatia and the Rule of Law) the new methodology of sentencing was suggested.

Now with the small time distance author noticed that suggested formula doesn't give the right results in all cases, so it had to be concluded it doesn't function properly and as it was pensive, and had to be changed and improved. 
criminal case law, which is the last line of defence of the legal order and society from unwanted conduct is of utmost importance. So, the stipulation or norms of the Criminal law should be very precise and well defined clear in order to reduce any ambiguity on what is allowed and what is not. Moreover, sentencing plays an important role in the harmonization of national case law. Despite this fact, the situation in reality is quite the opposite. Croatia has a very inconsistent case law. ${ }^{2}$ Such situation, in the end, leads to legal uncertainty.

Nonetheless, ssentencing is also important from an individual point of view. It affects all spheres of perpetrators life; private, business, public, politics, etc. So, the whole process of sentencing should be regulated the best way possible. Hence, if the sentence is measured properly, it will produce a positive effect and special and general deterrence will be fulfilled as punishment purposes. Therefore, the punishment should be precisely measured, specified, and should present the correct 'weight' of the offense. Furthermore, it is very important that all purposes of punishment to be achieved. ${ }^{3}$ Giving the proper judgment, proportional to the

2 Dragičević Prtenjača, M., "Utjecaj (nemetodološkog) odmjeravanja kazne na (ne)ujednačenost sudske prakse u Hrvatskoj i narušavanje tekovine vladavine prava" (eng. "The Influence of (NonMethodological) Sentencing on the (In)Consistency of the Case Law in Croatia and the Rule of Law) in Liber Amicorum Petar Novoselec: Kazneno pravo: sinergija teorije i prakse, 2019., pp. 134-138 and Munivrana Vajda, M., ,Domestic Trials for International Crimes - A Critical Analysis of Croatian War Crimes Sentencing Jurisprudence“, International Criminal Law Review, 19, 2019., pp. 15-38.

3 Purposes of punishment in Croatian criminal law are special and general deterrence and retributivism. Art. 41. Croatian Penal Code, OG, No., 125/2011, 144/2012, 56/2015, 61/2015, 101/2017, 118/2018

For more about purpose of punishment in Croatia which is very important for the issue of sentencing see - Bačić, F.; Bavcon, LJ.; Đorđević, M.; Kraus, B.; Lazarević, LJ.; Lutovac, M.; Srzentić, N.; Stajić, A., Komentar Krivičnog zakona Socijalističke Federativne Republike Jugoslavije, Savremena administracija i OOUR ,Savremena knjiga“, 1978., p 25.; Horvatić, Ž., Cvitanovć, L., Politika suzbijanja kriminaliteta, Zagreb, 1999.; Cvitanović, L., Svrha kažnjavanja u suvremenom kaznenom pravu,, Hrvatsko udruženje za kaznenopravne znanosti i praksu i Ministarstvo unutarnjih poslova Republike Hrvatske, Zagreb, 1999; Cvitanović, L., „Sustav propisivanja kazne zatvora u Kaznenom zakonu i Kaznenom zakoniku (De lege lata i De lege ferenda)“, Zbornik Pravnog fakulteta Sveučilišta u Rijeci, Vol. 25, no. 2, 2004.; pp 891920; Cvitanović, L., Svrha kažnjavanja u kaznenopravnim teorijama 19. st., Treći program hrvatskog radija, 2010.; Cvitanović, L., Fragmenti o konceptu svrhe kažnjavanja u kaznenom zakonodavstvu $i$ sustavu izvršenja kazne oduzimanja slobode 20. st., Treći program Hrvatskog radija, 2011.; Cvitanović, L., Fragmenti promišljanja svrhe kažnjavanja u filozofiji i kaznenopravnoj znanosti 20. stoljeća, Treći program Hrvatskog radija, 2011.; Bojanić, I.; Mrčela, M., „Svrha kažnjavanja u kontekstu šeste novele Kaznenog zakona“, Hrvatski ljetopis za kazneno pravo i praksu (Zagreb), Vol. 13, No. 2., 2006., pp. 431449; Damjanović, I.; Butorac, K., „Politika suzbijanja kriminaliteta: perspektive izvršenja kaznenopravnih sankcija“, Hrvatski ljetopis za kazneno pravo i praksu (Zagreb), Vol. 13, No. 2, 2006., pp. 657-684; Đurđević, Z., „Odluka o kazni - kaznenoprocesna pitanja“, Hrvatski ljetopis za kazneno pravo i praksu (Zagreb), Vol. 11, No.2, 2004., pp.751-782; Kos, D., Opće pravilo o izboru vrste i mjere kazne, $2004 .$, Available at: http://www.vsrh.hr/CustomPages/Static/HRV/Files/DKos-Opce_pravilo_o_izboru_vrst.. (20. IX. 2019.); Krvavica, M., Svrhe kažnjavanja u našem poslijeratnom i suvremenom krivičnom pravu, magistarska radnja branjena na Pravnom fakultetu Sveučilišta u Zagrebu, 1972.; Horvatić, Ž., Izbor kazne u jugoslavenskom krivičnom pravu i sudskoj praksi, Zagreb: Informator, 1980.; Horvatić, Ž.; Derenčinović, D.; Cvitanović, L., Kazneno pravo - opći dio 2, Kazneno djelo i kaznenopravne sankcije, Zagreb, 2017. pp. 219-222; Novoselec, P., Opći dio kaznenog prava, Osijek, 2016, p 366; Cirkveni, N., ,Zastrašivanje u kaznenoj politici Republike Hrvatske“, Zbornik Pravnog fakulteta u Rijeci, Vol. 31., No.1. 2010.

For more about retributivism see: Kelsen, H., Retribucija i kauzalnost, Zagreb, Naklada Breza, 2013 and Haist, M., Deterrence in a Sea of „Just Deserts“: Are Utilitarian Goals Achievable in a World of „Limiting Retributivism“, Journal of Criminal Law and Criminology , Vol. 99, Issue 3, 2009, pp. 789- 821; Available at: https://scholarlycommons.law.northwestern.edu/cgi/viewcontent. cgi? article $=7333 \&$ context $=$ jclc $(20.9 .2019$.) 
degree of guilt, sends a clear message on which behaviours are not allowed in the society. If the imposed penalties are rather mild, then what is the message that is being sent to the public? Is it that such behaviours are tolerated in the community, so no general deterrence will be achieved? Indeed, in Croatian case law, is not rear existence of mild sentencing in cases of serious crimes. ${ }^{4}$ This is not a good way to go. While it is true that the utter uniformity in the case law is not obtainable and that therefore efforts must primarily be made on educational level, the legislator should nevertheless strive toward producing certain instructions and guidelines which would help judges carry out more harmonized sentencing. Otherwise, the legislator is 'co-perpetrator' in legal uncertainty.

We remind you that almost $74 \%$ of punishment for first-degree murder cases in Croatia in the nine-year period were below the minimum (below 5 years which is minimum for first-degree murder) ${ }^{5}$.

The European Court of Human Rights (subsequently: ECtHR or Court) recognized the importance of consistent case law. According to ECtHR, inconsistent case law may lead to the violations of various provisions of the European Convention on Human Rights and Fundamental Freedoms (hereinafter: ECHR or Convention). Most frequently it represents the violation of Art 6 of the Convention the right to a fair trial, but often can violate the principles of legality (Art 7), and other principles (e.g. Right to respect for private and family life Art 8). Finally, the inconsistent case law leads to the violation of the principle of legal certainty as to the foundation of any legal order. So in that context, the principle of legality can be applied in cases of inconsistent case law as well as for the written law and both, in the systems of Anglo-Saxon lay and continental law

This is how the idea has arisen to give the judges in Croatia some „tool"which would improve the consistency of case law and how the formula of a possible methodology for sentencing was born.

\section{THE CONNECTION OF INCONSISTENT CASE LAW AND THE RULE OF LAW}

So what is the connection between inconsistent case law and the rule of the law? It is well known how inconsistence case law reduces citizen confidence in the judiciary, and how (the trust in) the judiciary should be one of the main pillars of society. Also, inconsistent case law causes legal uncertainty which then causes the demise of rule of law. When citizens lose their trust in the law, they will take the law and justice in their hands, and the chaos will arise. The rule of law in such scenario

4 For more see Dragičević Prtenjača, op. cit. note 2, pp. 134-138.

5 Dragičević Prtenjača, op. cit. note 2, pp. 134-138 and also see Mittermayer, "Presude na Županijskom sudu u Zagrebu za kazneno djelo ubojstva i teškog ubojstva od 1998. do 2002. Godine", Hrvatski ljetopis za kazneno pravo i praksu (Zagreb), Vol. 14, No. 1, 2007., p 97. 
loses the fight. That is why the consistent case law has big role in protection and preservation the rule of law.

In that context as it was noted before, ECtHR has also an important role, because it corrects the injustice and from the Court's standpoint, arbitrariness in contemporary society. So in case Ştefănică and Others v. Romania ${ }^{6}$ ECtHR has taken the position, the right to a fair trial is considered to be an integral part of the legal certainty and the rule of law. Furthermore, the legal certainty is the key part of the rule of law, and is considered to be one of the "key principles of democratic governance inherent in all convention provisions". ${ }^{7}$ Karas argues, just as it was mentioned earlier, although inconsistence case law is generally a violation of the right to a fair trial, ${ }^{8}$ it may also constitute a violation of different Convention rights depending on what values are detrimental to it, e.g. principle of legality, the right to respect for private and family life, ${ }^{9}$ etc. For substantive criminal law, the principle of legality is one of the most significant principles.

It should be emphasized how ECtHR considers practice and law as unity, two sides of the same coin that are inseparably linked. That's because the practice is the implementation of the law. Such understating is important from the aspect of the principle of legality and its application. The ECtHR currently comprehends the practice as part of the principle of legality in a broader sense, so it can be applied not only for the law as written regulations but also on practice as unwritten law. ${ }^{10}$ In its valuation ECtHR mainly observes the foreseeability and accessibility of the law, as well as competence of the body which applies the law, quality of the law and its implementation in practice which must be in accordance with the rule of law.

6 „, Right to a fair trial includes the right to legal certainty...

It recalls in this respect its case-law according to which the principle of legal certainty is implied in the Convention and constitutes one of the basic elements of the rule of law.".- Decision ECtHR Ştefănică and others v. Romania, Appl.no. 38155/02, 2. November, 2010., (Final 2.2.2011), § 31; Available at: https://hudoc.echr.coe.int/eng\#\{\%22fulltext\%22:[\%22\%C5\%9Etef\%C4\%83nic\%C4\%83\%22],\%22item id\%22:[\%22001-101491\%22]\} (20. I. 2019.).

Also for more see Karas, Ž., „Neujednačena sudska praksa u kaznenom postupku kao povreda Europske konvencije za zaštitu ljudskih prava“, Zbornik Pravnog fakulteta u Zagrebu, Vol. 64, No. 1, 2014., p 118.

7 Karas, op. cit. note 6, p 118

8 Karas points out that "in a number of ECtHR cases, the Court found violations of fairness due to inconsistent case law. For example, in Iordanov v. Bulgaria found that significant and persistent inconsistencies were used in the case-law and thus violated the fairness of the proceedings. Also in the Mullai v. Albania case, the ECtHR found a violation of fairness because the authorities acted inconsistent and violated the principle of legal certainty.- Karas, op. cit. note 6, pp. 118, 130.

9 As in case Kruslin v. France.- Decision ECtHR Kruslin v. France, Appl. no. 11801/85, 24. April, 1990; Available at: https://hudoc.echr.coe.int/eng\#\{\%22fulltext $\% 22:[\% 22$ Kruslin\%22],\%22itemid\%22: [\%22001-57626\%22]\} (20. I. 2019.).

10 Also see Karas, op. cit. note 6, p 114. 
In case Moiseyev v. Russia case, ${ }^{11}$ the Court argued, the principle of legality guaranteed by Art. 7. The European Convention for the Protection of Human Rights and Fundamental Freedoms (ECHR or Convention) is a fundamental element of the rule of law.

In this regard, the Court has taken the stance that the term law refers to a written and unwritten law as well as practical applications of law which is subject to an assessment of its accessibility and foreseeability. ${ }^{12}$

Karas further emphasize how ECtHR in its case-law accepted the standpoint of judicial interpretation as inevitable, irrespective of the system to which the state belongs (Anglo-Saxon or Continental). Especially this applies in cases of controversial or dubious situations where court interpretation is "a part of the legal tradition of continental states". ${ }^{13}$ So the law must be understood in the wider sense, even in the countries which belong to the continental system. The Court took mentioned standpoint in cases Förderkreis v. Germany, ${ }^{14}$ Kruslin v. France ${ }^{15}$ and Huvig $v$. France,${ }^{16}$ when it concluded how the law has the same meaning regardless

11 ,The Court reiterates that the guarantee enshrined in Article 7 of the Convention is an essential element of the rule of law. It is not confined to prohibiting the retroactive application of criminal law to the disadvantage of an accused. It also embodies, more generally, the principle that only the law can define a crime and prescribe a penalty (nullum crimen, nulla poena sine lege) and the principle that criminal law must not be extensively construed to the detriment of an accused, for instance by analogy. From these principles it follows that an offence must be clearly defined in law. This requirement is satisfied where the individual can know from the wording of the relevant provision and, if need be, with the assistance of the courts' interpretation of it, what acts and omissions will make him criminally liable“. - Decision ECtHR Moiseyev v. Russia, Appl. no. 62936/00, 9. October, 2008, (Final 6.4.2009.) § 233; Available at: https://hudoc.echr. coe.int/eng\#\{\%22fulltext\%22:[\%22Moiseyev\%22],\%22itemid\%22:[\%22001-88780\%22]\} (20. I. 2019.).

12 ,When speaking of "law" Article 7 alludes to the very same concept as that to which the Convention refers elsewhere when using that term, a concept which comprises written as well as unwritten law and implies qualitative requirements, notably those of accessibility and foreseeability...". - Decision ECtHR Moiseyev v. Russia, Appl. no. 62936/00, 9. October, 2008, (Final 6.4.2009.) § 233; Available at: https:// hudoc.echr.coe.int/eng\#\{\%22fulltext\%22:[\%22Moiseyev\%22],\%22itemid\%22:[\%22001-88780\%22]\} (20. I. 2019.). Also see Karas, op. cit. note 6, p 114.

13 Karas, op. cit. note 6, p 115.

14 "....the Court observes that it has always understood the term "law" in its "substantive" sense, not its "formal" one.... 'Law' must be understood to include both statutory law and judge-made "law"..-

Decision ECtHR Leela Förderkreis and others v. Germany, Appl. no.. 58911/00, 6. November 2008, (Final 6.2.2009) § 87; Available at: https://hudoc.echr.coe.int/eng\#\{\%22fulltext\%22:[\%22Leela\%20F\% C3\%B6rderkreis\%22],\%22itemid\%22:[\%22001-89420\%22]\} (20.1.2019.)

15 Decision ECtHR Kruslin v. France, Appl. no. 11801/85, 24. April, 1990.

16 ,The applicants said it was not. They submitted that there was no law in France governing the matter. France being a country of written law, case-law was a source only of law in general (droit), not of law in the statutory sense (loi)“.- Decision ECtHR Huvig v. France, Appl. no. 11105/84, 24. April, 1990, § 27; Available at: https://hudoc.echr.coe.int/eng\#\{\%22fulltext\%22:[\%22Huvig\%22], \%22itemid\%22:[\%22001-57627\%22]\} (20.1.2019.)

„...the Court points out, firstly, that it is primarily for the national authorities, notably the courts, to interpret and apply domestic law.... Settled case-law of this kind cannot be disregarded. In relation to paragraph 2 of Article 8 (art. 8-2) of the Convention and other similar clauses, the Court has always understood the term "law" in its "substantive" sense, not its "formal" one; it has included both enactments of lower rank than statutes .... and unwritten law...

In a sphere covered by the written law, the "law" is the enactment in force as the competent courts have interpreted it in the light, if necessary, of any new practical developments“. - Decision ECtHR Huvig v. France, Appl. no. 11105/84, 24. April, 1990., § 28; For more also see Karas, op. cit. note 6, p 114. 
of whether it was a written or unwritten law (court decisions). So in case Kruslin v. France the Court emphasized „...the Court has always understood the term "law" in its "substantive" sense, not its "formal" one; it has included both enactments of lower rank than statutes (see, in particular, the De Wilde, Ooms and Versyp judgment of 18 June 1971, Series A no. 12, p. 45, § 93) and unwritten law.... The 'law' is the enactment in force as the competent courts have interpreted it in the light, if necessary, of any new practical developments". ${ }^{17}$

The Court extended the meaning of law in the continental system on cases of practical implementation by competent authorities, in this context the courts. ${ }^{18}$ Therefore, even in the continental system, the principle of legality can be applied to court decisions, in other words case law. So, the ECtHR in case Belvedere Alberghiera S.r.l. against Italy, ${ }^{19}$ held the case law in Italy was inconsistent and in that regard contradictory to the principle of legality. The similar conclusion was reached in case Sierpinski v. Poland where it found a violation of the principle of legality and concluded how the Polish Supreme Court had failed to harmonize the practice. ${ }^{20}$

Inconsistent case law as emphasized by Karas can be the result of deliberate unlawfulness or an accidental one when the judgment is just different from standpoints usually held in case law. ${ }^{21}$

17 Decision ECtHR Kruslin v. France, Appl. no. 11801/85, 24. April, 1990, § 29.

18 - Decision ECtHR Huvig v. France, Appl. no. 11105/84, 24. April, 1990., § 28.

19 „The Court does not consider it necessary to decide in the abstract whether the role in the continental-law system of a rule, such as the constructive-expropriation rule, established by the courts is comparable to that of statutory provisions. However, it reiterates that the requirement of lawfulness means that rules of domestic law must be sufficiently accessible, precise and foreseeable..."

„In that connection, the Court observes that the case-law on constructive expropriations has evolved in a way that has led to the rule being applied inconsistently (see paragraphs 22 to 36 above), a factor which could result in unforeseeable or arbitrary outcomes and deprive litigants of effective protection of their rights and is, as a consequence, inconsistent with the requirement of lawfulness“. - Decsion ECtHR Belvedere Alberghiera S.r.l. v. Italy, Appl. no. 31524/96, 30. May, 2000, (Final 30.8.2000.) § 57., 58.; Available at: https://hudoc.echr.coe.int/eng\#\{\%22fulltext\%22:[\%22Belvedere\%22],\%22item id\%22:[\%22001-58834\%22]\} (20. I. 2019.).

20 „In the Court's opinion, the applicant seems to have fallen victim of the administrative reforms, the inconsistency of the case-law and the lack of legal certainty and coherence in this respect. As a result, the applicant was unable to obtain due compensation to which he was entitled."- Decision ECtHR Sierpiński v. Poland, Appl. no. 38016/07, 3. November 2009., (Final 3.2.2010.), § 79; Available at: https://hudoc.echr. coe.int/eng\#\{\%22fulltext\%22:[\%22Sierpinski\%22],\%22itemid\%22:[\%22001-95590\%22]\} (20.1.2019.)

The examples of the subsequent case-law in this matter show that the question of liability for damages resulting from flawed administrative decisions was by no means clear at the time the applicant's claim was examined and the divergences in the case-law continued several years late.." - Decision ECtHR Sierpiński protiv Poljske, $\$ 75$

„The Court has already held that divergences in case-law are an inherent consequence of any judicial system which is based on a network of trial and appeal courts with authority over the area of its territorial jurisdiction, and that the role of a supreme court is precisely to resolve conflicts between decisions of the courts below .... In the instant case, however, even the Supreme Court failed to have a uniform case-law on the legal questions in issue."- Decision ECtHR Sierpiński v. Poland, § 76

Decision ECtHR Sierpiński v. Poland, Appl. no. 38016/07, 3. November, 2009, (Final 3.2.2010.); Available at: https://hudoc.echr.coe.int/eng\#\{\%22fulltext\%22:[\%22Sierpinski\%22],\%22itemid\%22: [\%22001-95590\%22]\} (20. I. 2019.).

21 Karas, op. cit. note 6, p 121. 
Sometimes, that would be the case because of unclear regulations which could be interpreted in different ways and as such have a different meanings, while on the other hand, some interpretations would not be based on professional knowledge or scientific achievements and logic, ${ }^{22}$ but on arbitrariness. In such cases, it would represent an illegal interpretation which could be considered as analogy and violation of the principle of legality.

Interestingly as Karas also pointed out, ECtHR did not give particular importance to some special circumstance that occurred in the past, e.g. war or transitional period which could lead to different interpretations of the law and by that inconsistent case law, as well as to collision of norms in that period. ${ }^{23}$ It is well known, how during the transitional period the laws are often made without harmonization with other legal norms and legal order by itself, which can often lead to different doctrinal and court interpretations, resulting in the end with inconsistent case law. ${ }^{24}$

\subsection{The Role of the Constitutional and Supreme Courts in the Harmonization of National Case Law in Croatia and the protection of human rights}

The rights and fundamental freedoms guaranteed by the European Convention for the Protection of Human Rights and Fundamental Freedoms or better known as the European Convention on Human Rights, are also guaranteed by the Croatian Constitution.

22 Ibid., str. 121.

23 Ibid., str. 124.

24 For more about transitional justice and transitional law see: Roksandić Vidlička, S., Possible Future Challenge for the ECtHR?: Importance of the Act on Exemption and the Sanader Case for Transitional Justice Jurisprudence and the Development of Transitional Justice Policies, Zbornik Pravnog fakulteta u Zagrebu, 64, No. 5-6, 2014, pp. 1091-1119; Roksandić Vidlička, S., Prosecuting Serious Economic Crimes as International Crimes- A New Mandate for the ICC?, Duncker \& Humbolt, Berlin, 2017, pp. 189- 279.

Roksandić Vidlička, Sunčana, "Tranzicijska pravda kao metoda ostvarenja ustavnih vrednota uz analizu prakse Europskog suda za ljudska prava i odluke Ustavnog suda u predmetu Hypo", Liber amicorum Petar Novoselec- Kazneno pravo: sinergija teorije i prakse, Zbornik radova u čast profesora Petra Novoselca, ur. Turković, Ksenija; Munivrana Vajda, Maja; Dragičević Prtenjača, Marta, Pravni fakultet Sveučilišta u Zagrebu, Zagreb, 2019., pp. 435- 479.; Dolezal, D., "Organized Crime and Corruption in Croatia- A Criminological View", in Organized Crime and the Balkan Political Context. ed. Stoycho P. Stoychev. (Sofia: Risk Monitor Foundation Edition,), 2010, pp. 59-61; Available at: https://www.researchgate.net/ profile/Dalibor_Dolezal/publication/269628803_Organized_Crime_and_Corruption_in_Croatia_-_A Criminolgical_View/links/549004320cf214269f26463b/Organized-Crime-and-Corruption-in-Croatia-ACriminolgical-View.pdf (20. IX. 2019.).

Freeman, M., Truth Commissions and Procedural Fairness, Cambridge University Press, 2006; Available at: http://assets.cambridge.org/97805216/15648/frontmatter/9780521615648_frontmatter.pdf (20. IX. 2019.).

Teitel, Ruti G., "Transitional Justice Genealogy”, Harvard Human Rights Journal, 16, 2003, pp. 69-94.; Available at: https://www.qub.ac.uk/Research/GRI/mitchell-institute/FileStore/Filetoupload,757186,en. pdf (20. IX. 2019.).

Josipović, I., "Zastara u predmetima ratnog profiterstva i kriminala u pretvorbi i privatizaciji i kontroverze nakon odluke Ustavnog suda u predmetu Hypo", Hrvatski ljetopis za kaznene znanosti $i$ praksu (Zagreb), Vol. 25, No. 2, 2018., pp. 199-205. 
Related to that, the Constitutional Court of the Republic of Croatia plays a significant role. It guards the rights and freedoms guaranteed by the Croatian Constitution, the same rights and freedoms contained in the Convention. In that regard Constitutional Court indirectly affects the harmonization of case law.

The issue of inconstant case law was brought to the Constitutional Court. It concluded how inconsistent case law violates citizens' rights and legal certainty. ${ }^{25}$

It specially referred to the right to a fair trial in that context, which the Constitutional Court ${ }^{26}$ as well as European Court of Human Rights, consider being an intrinsic principle of legal certainty (of Vusić v. Croatia) ${ }^{27} .^{28}$ In the case of Vusić v. Croatia, the ECtHR also emphasized the obligation of each state to have valid mechanisms to ensure the harmonization of judicial practice. ${ }^{29}$

It is the fact, Courts in Croatia often impose different punishments for the same or similar offenses. Every case is unique and there are no two same cases, but Croatian case law differs so much that it is very close to arbitrariness.

ECtHR uses the notion of arbitrariness when interpretations of the law are contrary to the purpose of law and established practice. ${ }^{30}$ So arbitrariness and inequality can be a result of the ambiguity of the norms in order to allow courts to act and apply the law in similar situations. Such possibilities can be dangerous from

25 Decision of the Constitutional Court no, U-III-3488/2005, 27. February, 2008; for more also see Karas, op. cit. note 6, p 130

26 „In this respect, it should be noted that the European Court of Human Rights in Strasbourg (hereinafter: ECtHR) has interpreted the right to a fair trial within the meaning of Article $6 \S 1$ of the Convention for the Protection of Human Rights and Fundamental Freedoms (Official Gazette International Treaties "Nos. 18/97, 6/99 - consolidated text, 8/99 - correction, 14/02 and 1/06; hereinafter referred to as" the Convention ") as the inherent principle of legal certainty. One of the problems with which this principle is mentioned by, is the inconsistency of the case law in similar cases. - Decision of the Constitutional Court No. U-III-3356/2009, Zagreb, 20. March 2014., § 5.1

$27, \ldots$. the Court reiterates that one of the fundamental aspects of the rule of law is the principle of legal certainty, a principle which is implied in the Convention ".

Conflicting decisions in similar cases stemming from the same court which, in addition, is the court of last resort in the matter, may, in the absence of a mechanism which ensures consistency, breach that principle and thereby undermine public confidence in the judiciary... such confidence being one of the essential components of a State based on the rule of law. "- Decision ECtHR ESLJP Vusić v. Croatia, Appl. no. 48101/07, od 1. July, 2010, (Final 1.10.2010.) § 44

28 Decision of the Constitutional Court No. U-III-3356/2009, Zagreb, 20. March, 2014., § 5.1

In relation to this issue, the ECtHR expressed the following understanding in Vusić v. Croatia (Judgment, 1 July 2010, Application No. 48101/07, § 44): “... one of the fundamental aspects of the rule of law is the principle of legal certainty, the principle implicitly contained in the Convention (see Beian v. Romania (no. 1), no. 30658/05, § 39, ECHR 2007-XIII (excerpts). If there is no mechanism to ensure consistency, conflicting decisions in similar cases brought by the same court, which in addition constitutes the last instance in the legal matter in question, such situation may breach this principle and thereby undermine public confidence in the judiciary ... and the confidence is one of the most significant components of the state based on the rule of law. "

${ }^{29}$, The Contracting States have the obligation to organise their legal system so as to avoid the adoption of discordant judgments (see Vrioni and Others v. Albania, no. 2141/03, § 58, 24 March 2009). The Court considers that this reasoning applies a fortiori in the present instance where the same court reached conflicting decisions in the same case ". - Decision ECtHR Vusić v. Croatia. Appl. No. 48101/07, od 1. July, 2010, (Final 1. X. 2010.) § 44.

30 Ibid., p 122. 
the perspective of preventing arbitrariness. ${ }^{31}$ In order to prevent that, the corrective mechanism are set. In that role we can find the Supreme Court of Croatia (hereinafter: Supreme Court or SCC) as the primary and main corrective mechanism. ${ }^{32}$ It took the stance that action of the court is arbitrary when it significantly deviates from court practice ${ }^{33}$ and does not have the appropriate legal basis, when it's not based on properly determined facts, or is based on right facts but without proper assessment. Also such arbitrariness exists if it is not in accordance with the life logic, the rules of a particular profession, experience and professional knowledge. ${ }^{34}$ Supreme Court also took stance in line with ECtHR's view on this matter. So it concluded how laws must be accessible, precise and foreseeable in their application, in particular those which are of the custodial nature..$^{35}$

In the future, there is a possibility of partially taking over of the main task of the Supreme Court - harmonization of case law, by new Curt named High Criminal Court of the Republic of Croatia, after it's being founded in 2020. Although this is not explicitly placed in its jurisdiction (yet), this possibility is not to be discarded. This because by the norms of the Law on Criminal Procedure (hereinafter: the CPC) and the Law on Courts (hereinafter: the LC), ${ }^{36}$ it should have second instance jurisdiction on decision on appeals against the decisions of county courts in criminal cases, as well as other duties determined by law. So, there is a huge probability it will have a big influence on harmonization of the case law as well. ${ }^{37}$

\section{COMPARATIVE APPROACH - REVIEW OF PUNISHMENT MEASURING IN THE UNITED STATES AND MACEDONIA}

In order to gain insight into the sentencing as an important factor in the harmonization of the case law, we will take as the example the United States of

31 Ibidem.

32 „The Supreme Court of the Republic of Croatia shall: 1. ensure the uniform application of the rights and equality of all in its application..." - Art. 20. § 1. al. 1. The Law on Courts, OG, 28/2013, $33 / 2015,82 / 2015,82 / 2016,67 / 2018$

33 Karas, op. cit. note 6, p 122.

34 The Supreme Court in Case I-Kž-282/04 found that court decisions should not be arbitrary and that "decisions, in order to achieve the purpose of the judiciary, must be based on law, properly established facts and their correct assessment, which must be in accordance with the life logic, rules of the particular profession, experience and expertise. A judge's deliberate departure from these rules in making an individual decision means making an unlawful decision, which does not fall within the permissible scope of consuming the judiciary.”, SCC I Kž 282/04-5, 22. November, 2005. in Karas, op. cit. note 6, p 122.

$35, \ldots$ where national law allows for deprivation of liberty, that law must be sufficiently accessible, precise and predictable in its application to avoid the risk of arbitrariness ...".- Decision of the Supreme Court of Croatia II-Kž-148/15-4, 17. April, 2015; Available at: https://sudskapraksa.csp.vsrh.hr/ decisionText?id=090216ba80600658\&q=arbitrarn (20. IX. 2019.).

36 The Law on Courts OG, 28/2013, 33/2015, 82/2015, 82/2016, 67/2018.

37 It remains to be seen how and to what extent this court will contribute to the harmonization of case law. One of the questions is why it was necessary to establish it in the first place, why the problem was not solved by the appointment of more judges to the criminal department of the Supreme Court of the Republic of Croatia? 
America (hereinafter referred to as the USA), which belongs to the Anglo-Saxon system and Macedonia belonging to the continental system. Both of them have regulations which determine the methodology of sentencing what is especially important to the subject of harmonization of case law.

\subsection{United States of America}

In the United States in 1987, the so-called Sentencing Guidelines were issued. ${ }^{38}$ They were amended a few times till today. ${ }^{39}$ Guidelines are used by judges when determining punishment. In that process, they are using Sentencing Table which was created by United States Sentencing Commission. Most likely, one of the reasons for their existence as Green emphasized is because of the enormous discretion of judges in the USA when delivering/rendering the judgment. ${ }^{40}$ The punishment is calculated by looking at the table in which are 43 levels of criminal offenses on the vertical axis (each criminal offense is classified into one of the 43 levels in the Sentencing Guidelines), and on the horizontal axis the points are divided into six categories. ${ }^{41}$ The horizontal axis is actually an axis with points for each circumstance which is important for judgment, and all of those points are being summed up, and the judgment is rendered. The imprisonment frame is then made when looking simultaneously at both axes. Penalties are indicated in the months. ${ }^{42}$ Interestingly, range of punishment is not stipulated for each criminal offense just beneath its definition, but incrimination contains only a category (eg. 42), which is the mark for the severity of the offense. Also, there is another table in which it is indicated for which category (of the offense) the sentence of imprisonment can be imposed. ${ }^{43}$

However, as the name of the document says, the Guidelines are non-mandatory. In other words, the judge may digress from them or not apply them at all, but then

38 About punishment in Anglo-Saxon system, especially in the United Kingdom was written by Ashworth, A. (2003) Sentencing \& Criminal Justice, Butterworths LexisNexis and Thomas, D. A., Principles of Sentencing, Heinemann London, 1970.

39 Pryor Jr. W.H.; Barkow, C. E.; Breyer, C. R.; Reeves, D. C.; Rybicki, D.; Cushwa, P. K., Guidelines Manual, United States Sentencing Commission, §3E1.1, Nov. 2018; Available at: https://www.ussc.gov/ guidelines/2018-guidelines-manual (20. XI. 2018.).

40 Green, E., Judicial Attitudes in sentencing, London MacMillan \& Co Ltd, New York St. Martin's Press, 1961, p 1 .

41 The horizontal axis is also called the Criminal History Category and is divided into six categories. They scored 0 or 1 point in Category I .; II. category 2 and 3 points; III. category 4,5,6, points; IV. 7,8,9 points; V. category10,11,12, points and VI. Category 13 and above. -United States Sentencing Commission, Guidelines Manual, §3E1.1 (Nov. 2018); p 407.

42 Explanation of the method of determining the sentence according to Sentencing Table, see in United States Sentencing Commission, Guidelines Manual, §3E1.1 (Nov. 2018); p 12.

43 For criminal offences of the categories 12 to 16 imprisonment of 1 to 5 years can be imposed for categories 17 to 23, imprisonment of 5 to 10 years may be imposed; for categories 24 to 28, imprisonment of 10 to 15 years; for categories 29 to 31 , imprisonment of 15 to 20 years; for categories 32 to 33 , imprisonment of 20 to 25 years; from the 34 to 36 category, imprisonment for more than 25 years can be imposed, and from the 37th category the sentence of life imprisonment can be imposed.- United States Sentencing Commission, Guidelines Manual, §3E1.1 (Nov. 2018); p 395. 
he must specifically explain why he does it. In any case, they are a big help to judges and also are influencing on harmonization of sentencing and case law in the end.

Sentencing Guidelines provide relative legal certainty because at least it is clear how they should be applied and they contain the methodology to do it, to make a judgment, and they are available to everyone online. The methodology is specified, and it is precisely determined how the courts have to deal with the punishment and what is the framework for that. Of course it is impossible to know at the beginning for each case what would be the duration of punishment, but nevertheless, there is some sort of legal certainty.

In Croatian case law, there is nothing of such kind (some sort of guidelines). The circumstances relevant to determine the correct measure of the punishment are assessed in each case and are left to each judge to decide upon them individually. Generally, they are divided into generic groups in Croatian Penal Code (hereinafter: CPC) ${ }^{44}$ but without adding any points or something what would made them measurable. So judges have a huge discretion which circumstance they will be evaluating and how- as aggravated or mitigating circumstances.

Hence, it would be incorrect to say that there is some sort of the methodology of sentencing in Croatia. The fact is there is none. So the question is why? Why the law gives such discretion to the judges when it is the fact that case law in Croatia is inconsistent?

\subsection{Macedonia}

Macedonia is particularly interesting regarding sentencing. A special Law for the Determination of the Type and Duration of Sentence (hereinafter: the Sentencing Act) came into force in 2015. It regulates the sentencing process and methodology of punishment. ${ }^{45}$ However, it caused many controversies in Macedonian criminal doctrine and practice. ${ }^{46}$ The special concern was brought because a lot of solutions which existed in the guidelines of the State Attorney's Office were accepted,

44 Croatian Penal Code, OG, No., 125/2011, 144/2012, 56/2015, 61/2015, 101/2017, 118/2018 also for Determination of Penalty see Art 47 CPC.

„(1) When determining the type and measure of punishment, the court shall, starting from the degree of guilt and the purpose of punishment, assess all the circumstances affecting the severity of punishment by type and measure of punishment (mitigating and aggravating circumstances), and especially the degree of threat to or violation of a legally protected good, motive for having committed the criminal offence, degree to which the perpetrator's duties have been violated, manner of commission and the consequences arising from the commission of the criminal offence, perpetrator's prior life, his/her personal and pecuniary circumstances and his/her conduct following the commission of the criminal offence, relationship to the victim and efforts to repair the damage.

(2) The severity of punishment shall not exceed the degree of guilt."

45 The Law for the Determination of the Type and Duration of Sentence has been brought in December the $30^{\text {th }}$ 2014. and entered into force in June $7^{\text {th }}$ 2015. - Lazetic Buzarovska, G.; Tupanceski, N.; Mujoska, E., Mandatory Sentencing Guidelines: The Case Of Macedonia, European Scientific Journal August, edition Vol.12, No.22 ISSN: 1857 - 7881 (Print) e - ISSN 1857- 7431, 2016, p 89; Available at: http://eujournal.org/index.php/esj/article/view/7941/7640 (20. IX. 2018.).

46 Ibid. 
rather than solutions in court guidelines. ${ }^{47}$ Also, a big problem was because by the Sentencing Act all solutions which initially existed as non-mandatory guidelines, now were mandatory. That caused the big concern among judges because by their opinion there was an appearance that Penal Code is less relevant in sentencing than the Sentencing Act, ${ }^{48}$ and they became 'only the mouth of the law'. So Lazetic Buzarovska, Tupacenski and Mujoska conclude how this form of "practice of determination of sanction is not acceptable for countries with civil law tradition". ${ }^{9}$

By Lazetic Buzarovska, Tupacenski and Mujoska, such regulation leaves very little room for judges to discern the mitigating and aggravating circumstances of punishment. Legal provisions are neither guidance nor assistance to judges, but the mandatory provisions that judges have to apply. Once a court finds that a criminal offense has been committed, it begins with the calculation of all mitigating or aggravating circumstances. It is calculated in the way that points are added or subtracted, and the starting point is the middle of the sentencing range for that particular offense which is specified in the vertical category of the table attached to that law. ${ }^{50}$ There are nine categories of mitigating and aggravating circumstances that affect the height of the sentence. ${ }^{51}$ These are the degree of guilt; motivation for committing a criminal offense; probability of occurrence of danger or violation of protected goods; the circumstances under which the criminal offense was committed; contribution of the victim; former conviction and perpetrators behaviour; personal circumstances of perpetrators and behaviour after the criminal offense; other circumstances in connection to the perpetrator's personality and previously committed criminal offenses, and the ninth category includes circumstances such as a homogeneous recidivism (he has committed the same or similar offenses now and before); same motives; the time that has elapsed since the commission of previous criminal offense, a punishment or a pardon. ${ }^{52}$ The above-mentioned circumstances are also prescribed by the Macedonian Penal Code (hereinafter: the MPC). ${ }^{53}$ The MPC stipulates guilt, the severity of the offense and purpose of sentencing as necessary and basic for proper sentencing. ${ }^{54}$ During this process the court especially has to have in mind the effect of the punishment on the perpetrator, his personality and possibility his re-socialization. ${ }^{55}$ The individualization of sentencing is also

47 Ibid., p 95.

48 Lazetic Buzarovska et al. op. cit. note 43, p 102.

49 Lazetic Buzarovska et al. op. cit. note 43, p 88.

50 The tables were not attached to the article, so it was not possible to see how tables looked like.

51 Lazetic Buzarovska et al. op. cit. note 43, p 98.

52 Ibid., $\mathrm{p}$ 99. Each of these circumstances is subdivided into subcategories, or circumstances which carry a certain number of points.

53 Art 39 § 2, § 4 Macedonian Penal Code; Available at: https://www.legislationline.org/documents/ action/popup/id/16066/preview (20. IX. 2018.).

It should be noted the version of the MPC which was consulted was amended in 2009.

54 Art 39 § 1 MPC.

55 Art 39 § 3 MPC. 
accomplished by other criminal law institutes such as exemption from punishment, mitigation of punishment, etc. ${ }^{56}$

The Sentencing Act established a Special Commission on Harmonization of Criminal Policy whose task, inter alia, is to monitor and analyse the court proceedings in the courts in the Republic of Macedonia and take into consideration the purpose of punishment. ${ }^{57}$ The Commission is composed of seven members which are to be elected by Parliament with a mandate of four years. ${ }^{58}$ The existence of this Commission is what is very controversial and caused a great debate about its constitutionality in practice and public, and among legal scientist in Macedonia.

\section{PREVIOUS FORMULA AND THE NEW ONE}

To uniform the case law and to give the tool to the judges which would ease them the ruling and sentencing, there was an idea to give them the formula for sentencing. It would not be mandatory, but it would be sort of help when evaluating the circumstances and measuring the punishment.

So the author came up with the formula, mathematically defined the length of the sentence with the formula: $\mathrm{X}=\max \{\mathrm{Z}, \min \{1 / 2 \mathrm{~N}+\mathrm{h} \times(\mathrm{A} 1+2 \mathrm{~A} 2-\mathrm{B} 1-2 \mathrm{~B} 2)$, Y\}\}.

Where:

A1 ... The number of aggravating circumstances which carry one point

A2 ... Each of the circumstances from this class increases the final penalty for the total amount of $2 \mathrm{~h}$

B1 ... The number of mitigating circumstances which carry one point

B2 ... The number of mitigating circumstances which carry two points (2h)

Y ... Maximum possible penalty length (special or general maximum)

$\mathrm{Z}$... Minimum penalty length (special or general minimum)

$X$... Length of the Sentence (Penalty)

$\mathrm{N}$ is the range, (the maximum - the minimum penalty prescribed) $=\mathrm{Y}-\mathrm{Z}$

$\mathrm{h}$ is the number of months corresponding to "one point",

$\mathrm{h}=\mathrm{N} /$ total number of circumstances $=\mathrm{N} /(\mathrm{A} 1+\mathrm{A} 2+\mathrm{B} 1+\mathrm{B} 2)$

56 Art 40. MPC and mitigation limits are prescribed by Art 41 MPC.

57 Ibid., p 93.

58 Ibid., p 94. Two members are elected on the proposal of the State Attorney's Office, two on the proposal of the Judicial Council, one on the proposal of the Bar, one of the professors who teach criminal law on the proposal of extinguished Universities in Macedonia and one member of the professors on the proposal of the Ministry of Justice. Lazetic Buzarovska et al. are very critical not only of the purpose of the Commission, but also of the manner in which individual members are selected, especially the member, that is, the professor who is elected at the proposal of the Ministry of Justice. 
The idea was to evaluate the circumstances important for punishment by giving them some points, which would worth a certain number of days (in prison up to 6 months), months or years (in long-term imprisonment). For example, if a court in a certain case finds 3 aggravating circumstances and 4 mitigating, this would be a total of 7 circumstances. Each circumstance would be worth one point unless some circumstances dominate and then the court can decide that this specific circumstance carries (or worth) 2 points (such as the degree of guilt or other relevant circumstance in some case). These points we multiply with months. So how shall we know how many months carry each circumstance?

If we have a range of sentencing form 6 months to 5 years, the range is 54 months. Then we divide the 54 with 7 , and then we know that each circumstance is worth approximately 7 months (and about 21 days, which would not normally play a role because the prison sentence is usually pronounced in months).

So, in this example, if the court founds 7 circumstances which carry (by his discretional decision) one point, each circumstance would be worth 7 months. If it founds one circumstance which would carry 2 points, then this circumstance would worth 14 months. I'm of the opinion that no circumstance should carry more than 2 points or less than 1 . So suggested range of points is 1 to 2 . Two points should carry circumstance which is prevalent or dominant circumstance.

So from where we should start. From the begging or minimum of the sentence in our example 6 months or form the middle of the range (6 months to 5 years), which would be 2 years and 3 months or 27 months.

We suggest to start from the middle and not from the minimum because if we start from the minimum every mitigating circumstance would be a particular mitigating circumstance which would determine the sentence below the 6 months which is the minimum of the range in our case. That would not be a good solution.

So if we start from the middle or 27 months, the worth of 3 aggravating circumstances would be 21 months ( 3 circumstances multiple by 7 months if all three of them carry 1 point) and the sentence would be their sum or 48 months or 4 years.

The sentence would be four years if there were only three aggravating circumstances. But in our case, we have 4 mitigating circumstances and when we convert them into months their worth would be 28 months. Those mitigating circumstances we have to subtract from the sanction of 4 years, or 48 months (48$28=20$ ), so the difference which is also our sentence is 20 months or 1 year and 8 months. So the final sentence would be 1 year and 8 months in the hypothetical example.

The sentencing should imply firstly adding the aggravating circumstances and then subtract from the sum the mitigating circumstances.

If we go in the opposite direction, first by subtracting the mitigating circumstance form the middle, it might happen that the sentence enters the minus, which would mean mitigating the punishment below its minimum or below rang of 6 months, and that is not a right way to do, nor to get the right result. 
Also, if the calculation of the sentence exceeds the maximum limit of 5 years (in our hypothetical case) then the sentence should be the special maximum or 5 years in our case. The reason lies in the fact that Croatian criminal law doesn't know the aggravation of the sentence when sentence can exceed the special maximum, but knows the mitigation of the sentence when it can go below special minimum (in our case below 6 months), so-called reduction of sentence. So, the judges can rule the sentence below 6 months but not beyond 5 years (in our case).

When we spin the model we noticed there is a problem. In the hypothetical case where it would be only one mitigating circumstance, this formula would give the minimum of the sentence as the final sentence. This is wrong. So we understood the model is not working in every situation no matter how hypothetical it is.

So the formula had to be corrected. The only thing that is changed, is $\mathbf{h}$. So the formula stayed the same but the $\mathbf{h}$ is no longer $=\mathrm{N} / \mathrm{A} 1+\mathrm{A} 2+\mathrm{B} 1+\mathrm{B} 2(\mathrm{~h}=\mathrm{N} /$ total number of circumstances $=\mathrm{N} / \mathrm{A} 1+\mathrm{A} 2+\mathrm{B} 1+\mathrm{B} 2)$ but N/12 (h=N/12).

We decided to take number 12 because there are 12 months in one year and custodial sentences are usually imposed in years and months, and our calculation of sentence is made in months.

The new mathematical calculation described above can be represented by the formula:

$$
\mathrm{X}=\max \{\mathrm{Z}, \min \{1 / 2 \mathrm{~N}+\mathrm{h} \times(\mathrm{A} 1+2 \mathrm{~A} 2-\mathrm{B} 1-2 \mathrm{~B} 2), \mathrm{Y}\}\}
$$

A1 ... The number of aggravating circumstances which carry one point

A2 ... Number of two-point random circumstances (2h)

B1 ... The number of mitigating circumstances which carry one point

B2 ... The number of mitigating circumstances which carry two points (2h)

Y ... Maximum possible penalty length (special or general maximum)

$\mathrm{Z}$... Minimum penalty length (special or general minimum)

$X$... Height of the Sentence

$\mathrm{N}$ is the range, (the maximum - the minimum penalty prescribed) $=\mathrm{Y}-\mathrm{Z}$

$\mathrm{h}$ is the number of months corresponding to "one point",

\section{$\mathrm{h}=\mathrm{N} / \mathbf{1 2}$}

If $\mathrm{h}$ is $\mathrm{N} / 12$, the mathematical formula will work in all situations and hypothetical cases except the mitigation of sentence for which situation we will have to make a new formula.

So in our example when $\mathrm{N}$ is 54 months, and where we have 4 mitigating circumstances and 3 aggravating, and by the assumption that all circumstances carry one point, we should follow the same calculation. So we divide 54 months $(\mathrm{N})$ with 12 months (according to new formula) and we get how many points carry each circumstance. So each circumstance worth's 4,5 months $(h=N / 12$, or 54/12). Now 
we multiply h with 3 aggravating circumstances. So we get the number 13,5 months which we sum to middle of the range or 27 months and the sentence would be 40,5 months if there are only three aggravating circumstance. But in our case there are four mitigating circumstances as well, so we should multiply 4 with the $\mathrm{h}$ (point of the circumstance) 4,5 and we get 18 months. So from 40,5 months we have to subtract 18 months and we get the X or 'Height of the Sentence' which would be 22,5 months or 1 year, 10 months and 15 days. Because the days won't play a role we can say the $X$ or the sentence is going to be 1 year and 10 months.

Sentencing for the concurrence of the criminal offenses should follow the same path. After determining each individual sentence, the court must establish a range of the special sentence for the concurrence of the offenses. In Croatia, the so-called 'the method of aspiration' is accepted and there is no accumulation of the sentences. By this rule sentence for the concurrence of the offenses must be higher than the highest individual determined sentence and less than the sum of the all penalties imposed. This is the range in which a sentence for concurrence of the offenses is to be determined and imposed. Once the range is established, the procedure of sentencing should be the same - first it should be determined the middle then the aggravating circumstance should sum up, and after the mitigating circumstances should subtract. This aggravating and mitigating circumstances can be original or derivative in cases of concurrence of the offenses. ${ }^{59}$

During this sentencing process, the court should always have in mind the guilt as the basis and measure of the sentence. This because the degree of the guilt is one base for sentencing, and the other is the purpose of the sentencing. So the sentence should not exceed the degree of guilt because it is limited by guilt but may go below that limit if it is in accordance with the realization of special and general prevention.

In the end, the formula should help the judges to determine the sentence and help them in the sentencing process.

\section{CONCLUSION}

Harmonization of court practice is a very important issue, with far-reaching consequences. It affects the development of court practice in an unthinkable way. The court interpretation of the norms has far-reaching consequences especially in the imposition of the law. Baring that in mind, unification and the consistency of case law is of the utmost importance because it is also the guardian of the rule of law.

Therefore, the penalties must be measured properly and in accordance with the law on how all-purposes of sentencing would be fulfilled. Hence the sentencing process should have the rules, nonetheless methodology which would ease the judges this process.

59 For more about original and derivative circumstances see Novoselec (2016), op. cit. (note 3), p 433. 
Although the Lazetic Buzarovska, Tupacenski, and Mujoska considered how USA model of sentencing (with Sentencing Guidelines) is not the right solution for civil or continental law system, the author are of the opinion that is better such than none. But author partially agree with Lazetic Buzarovska, Tupacenski and Mujoska how USA model doesn't fit entirely in civil law system. That's why author give their one solution - 'the formula'.

\section{BIBLIOGRAPHY}

1. Ashworth, A., Sentencing \& Criminal Justice, Butterworths LexisNexis, 2003.

2. Bačić, F.; Bavcon, LJ.; Đorđević, M.; Kraus B.; Lazarević, LJ.; Lutovac, M.; Srzentić, N.; Stajić, A., Komentar Krivičnog zakona Socijalističke Federativne Republike Jugoslavije, 'Savremena administracija' i Oour 'Savremena knjiga', 1978.

3. Bojanić, I.; Mrčela, M., Svrha kažnjavanja u kontekstu šeste novele Kaznenog zakona, Hrvatski ljetopis za kazneno pravo i praksu (Zagreb), Vol. 13, No. 2., 2006, pp. 431.449.

4. Cirkveni, N., Zastrašivanje u kaznenoj politici Republike Hrvatske, Zbornik Pravnog fakulteta u Rijeci, Vol. 31., No.1, 2010.

5. Cvitanović, L., Svrha kažnjavanja u suvremenom kaznenom pravu, Hrvatsko udruženje za kaznenopravne znanosti i praksu i Ministarstvo unutarnjih poslova Republike Hrvatske, Zagreb, 1999.

6. Cvitanović, L., Sustav propisivanja kazne zatvora u Kaznenom zakonu i Kaznenom zakoniku (De lege lata i De lege ferenda), Zbornik Pravnog fakulteta Sveučilišta u Rijeci, Vol. 25, No. 2., 2004, pp. 891.-920.

7. Cvitanović, L., Svrha kažnjavanja u kaznenopravnim teorijama 19. st., Treći program hrvatskog radija, 2010.

8. Cvitanović, L., Fragmenti o konceptu svrhe kažnjavanja u kaznenom zakonodavstvu i sustavu izvršenja kazne oduzimanja slobode 20.st., Treći program Hrvatskog radija, 2011.

9. Cvitanović, L., Fragmenti promišljanja svrhe kažnjavanja u filozofiji i kaznenopravnoj znanosti 20. stoljeća, Treći program Hrvatskog radija, 2011.

10. Damjanović, I.; Butorac, K., Politika suzbijanja kriminaliteta: perspektive izvršenja kaznenopravnih sankcija, Hrvatski ljetopis za kazneno pravo i praksu (Zagreb), Vol. 13, No. 2, 2006, pp. 657-684.

11. Dolezal, D., Organized Crime and Corruption in Croatia- A Criminological View, in Organized Crime and the Balkan Political Context. ed. Stoycho P. Stoychev. (Sofia: Risk Monitor Foundation Edition,), 2010, pp. 59-61; Available at: https://www.researchgate.net/profile/Dalibor_Dolezal/publication/269628803_ Organized_Crime_and_Corruption_in_Croatia_-_A_Criminolgical_View/ links/549004320cf214269f26463b/Organized-Crime-and-Corruption-in-Croatia-ACriminolgical-View.pdf (20.9.2019.)

12. Đurđević, Z., Odluka o kazni - kaznenoprocesna pitanja, Hrvatski ljetopis za kazneno pravo i praksu (Zagreb), Vol. 11, No. 2, 2004, pp. 751-782. 
13. Freeman, M., Truth Commissions and Procedural Fairness, Cambridge University Press, 2006; Available at: http://assets.cambridge.org/97805216/15648/ frontmatter/9780521615648_frontmatter.pdf (20.9.2019.)

14. Green, E., Judicial Attitudes in sentencing, London MacMillan \& Co Ltd, New York St. Martin's Press, 1961.

15. Haist, M., Deterrence in a Sea of „Just Deserts “: Are Utilitarian Goals Achievable in a World of „Limiting Retributivism“, Journal of Criminal Law and Criminology, Vol.99, Issue 3., 2009; pp. 789- 821; Available at https://scholarlycommons.law. northwestern.edu/cgi/viewcontent.cgi?article=7333\&context=jclc (20.9.2019.).

16. Horvatić, Ž., Izbor kazne u jugoslavenskom krivičnom pravu i sudskoj praksi, Zagreb, Informator, 1980.

17. Horvatić, Ž.; Derenčinović, D.; Cvitanović, L., Kazneno pravo- Opći dio 2, Kazneno djelo i kaznenopravne sankcije, Pravni fakultet Sveučilišta u Zagrebu, Zagreb, 2017.

18. Josipović, I., Zastara u predmetima ratnog profiterstva $i$ kriminala u pretvorbi $i$ privatizaciji i kontroverze nakon odluke Ustavnog suda u predmetu Hypo, Hrvatski ljetopis za kaznene znanosti i praksu (Zagreb), Vol. 25, No. 2, 2018, pp. 199-205.

19. Karas, Ž., Neujednačena sudska praksa u kaznenom postupku kao povreda Europske konvencije za zaštitu ljudskih prava, Zbornik Pravnog fakulteta u Zagrebu, Vol. 64, No. 1, 2014, pp. 111-131.

20. Kelsen, H., Retribucija i kauzalnost, Zagreb, Naklada Breza, 2013.

21. Kos, D., Opće pravilo o izboru vrste i mjere kazne, 2004; Available at: http:// www.vsrh.hr/CustomPages/Static/HRV/Files/DKos-Opce_pravilo_o_izboru_vrst... (20.9.2019.)

22. Krvavica, M., Svrhe kažnjavanja u našem poslijeratnom i suvremenom krivičnom pravu, Magistarska radnja branjena na Pravnom fakultetu Sveučilišta u Zagrebu, 1972.

23. Lazetic Buzarovska, G.; Tupanceski, N.; Mujoska, E., Mandatory Sentencing Guidelines: The Case Of Macedonia, European Scientific Journal August, edition Vol.12, No.22 ISSN: 1857 - 7881 (Print) e - ISSN 1857- 7431, 2016; Available at: http://eujournal.org/index.php/esj/article/view/7941/7640 (20.9.2018.).

24. Mittermayer, O., Presude na Županijskom sudu u Zagrebu za kazneno djelo ubojstva $i$ teškog ubojstva od 1998. do 2002. godine, Hrvatski ljetopis za kazneno pravo i praksu (Zagreb), Vol. 14, No. 1, 2007, pp. 77-140.

25. Munivrana Vajda, M., Domestic Trials for International Crimes - A Critical Analysis of Croatian War Crimes Sentencing Jurisprudence, International criminal law review, 19, 2019, pp. 15-38.

26. Novoselec, P., Opći dio kaznenog prava, Osijek, 2016.

27. Pryor Jr. W.H.; Barkow, C.E.; Breyer, C. R.; Reeves, D. C.; Rybicki, D.; Cushwa, P. K., Guidelines Manual, United States Sentencing Commission, §3E1.1 (Nov. 2018); Available at https://www.ussc.gov/guidelines/2018-guidelines-manual (20.9.2019.).

28. Roksandić Vidlička, S., Possible Future Challenge for the ECtHR?: Importance of the Act on Exemption and the Sanader Case for Transitional Justice Jurisprudence 
and the Development of Transitional Justice Policies, Zbornik Pravnog fakulteta $\mathrm{u}$ Zagrebu, Vol. 64, No. 5-6, 2014, pp. 1091-1119.

29. Roksandić Vidlička, S., Prosecuting Serious Economic Crimes as International Crimes- A New Mandate for the ICC?, Duncker \& Humbolt, Berlin, 2017.

30. Roksandić Vidlička, S., Tranzicijska pravda kao metoda ostvarenja ustavnih vrednota uz analizu prakse Europskog suda za ljudska prava i odluke Ustavnog suda u predmetu Hypo, Liber amicorum Petar Novoselec- Kazneno pravo: sinergija teorije i prakse, Zbornik radova u čast profesora Petra Novoselca, Zagreb, 2019., pp. 435479.;

31. Teitel, Ruti G., Transitional Justice Genealogy, Harvard Human Rights Journal,16, 2003, pp. 69-94.; Available at: https://www.qub.ac.uk/Research/GRI/mitchellinstitute/FileStore/Filetoupload,757186,en.pdf (20.9.2019.)

32. Thomas, D. A., Principles of Sentencing, Heinemann London, 1970.

\section{NOVA MOGUĆNOST METODOLOGIJE IZRICANJA KAZNE U HRVATSKOJ DE LEGE FERENDA - NOVA POBOLJŠANA FORMULA}

Neujednačena sudska praksa pokazuje se kao relativno veliki problem jer među ostalim utječe na povjerenje u pravnu sigurnost i vladavinu prava. U pozadini ovog problema nalazi se proces odmjeravanja kazne. U Hrvatskoj ne postoji metodologija za odmjeravanja kazne. Hrvatski Kazneni zakon sadrži norme koje reguliraju svrhu kazne i u nekom generičkom obliku propisuje okolnosti koje mogu biti relevantne za odmjeravanje kazne, ali Kazneni zakon ništa ne govori o samom procesu, niti o tome kako pristupiti odmjeravanju, odnosno o metodologiji. Tijekom postupka odmjeravanja sud se mora voditi svrhom kažnjavanja, te stupnjem počiniteljeve krivnje, i u skladu s njima pravilno izabrati vrstu i mjeru kazne, odnosno odmjeriti kaznu koja bi bila primjerena i odgovarala počinjenom kaznenom djelu i njegovoj težini. Dakle, kako ne postoji metodologija, ne može se sa sigurnošću utvrditi da je sam postupak odmjeravanja kazne bio lege artis. U tom smislu, autori daju svoj prijedlog o mogućem rješenju ovog problema i materije. Predlažu uvođenje „formule“ za odmjeravanje kazne u hrvatski kazneno-pravni sustav koja ne bi bila obveznog karaktera. Formula je poboljšana i bolja od prethodne formule, jer su otklonjeni neki uočeni nedostaci. Autori smatraju da bi „formula“ trebala pridonijeti usklađivanju sudske prakse u Hrvatskoj i očuvanju načela pravne sigurnosti i vladavine prava. Slična rješenja već postoje u Makedoniji koja pripada kontinentalnom pravnom krugu od 2015. kada je donesen Zakon o određivanju vrste i trajanja kazni i u Sjedinjenim Američkim Državama od 1987. godine kada su donesene Smjernice o kazni ili tzv. Sentencing Guidelines.

Ključne riječi: neujednačena sudska praksa, odmjeravanje kazne, metodologija, vladavina prava, formula 